\title{
The Chemopreventive Effect of Tanacetum Polycephalum Against LA7-Induced Breast Cancer in Rats and the Apoptotic Effect of a Cytotoxic Sesquiterpene Lactone in MCF7 Cells: A Bioassay-Guided Approach
}

\author{
Hamed Karimian ${ }^{a}$ Mehran Fadaeinasab ${ }^{b}$ Soheil Zorofchian Moghadamtousib \\ Maryam Hajrezaei ${ }^{a}$ Maryam Zahedifard ${ }^{a}$ Mahboubeh Razavi ${ }^{a}$ \\ Sher Zaman Safic Syam Mohan ${ }^{d}$ Shaden A.M. Khalifae Hesham R. El-Seedie,f \\ Mahmood Amin Abdullag Hapipah Mohd Ali ${ }^{b}$ Mohamad Ibrahim Noordina \\ aDepartment of Pharmacy, Faculty of Medicine, University of Malaya, 'bepartment of Chemistry, \\ Faculty of Science, University of Malaya, 'Department of Medicine, Faculty of Medicine, University \\ of Malaya, Kuala Lumpur, Malaysia; 'Medical Research Centre, Jazan University, Jazan, Kingdom of \\ Saudi Arabia; 'Department of Experimental Hematology, Karolinska University Hospital, Stockholm, \\ fDivision of Pharmacognosy, Department of Medicinal Chemistry, Uppsala University, Uppsala, Sweden; \\ gDepartment of Biomedical Science, Faculty of Medicine, University of Malaya, Kuala Lumpur, Malaysia
}

\section{Key Words}

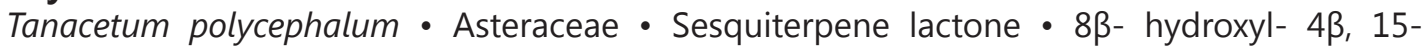
dihydrozaluzanin C • Breast cancer • Apoptosis $\bullet$ LA7 cells $\bullet$ MCF7 cells

\begin{abstract}
Background: Tanacetum polycephalum L. Schultz-Bip is a member of the Asteraceae family. This study evaluated the chemopreventive effect of a T. polycephalum hexane extract (TPHE) using in in vivo and in vitro models. Methods and Results: Five groups of rats: normal control, cancer control, TPHE low dose, TPHE high dose and positive control (tamoxifen) were used for the in vivo study. Histopathological examination showed that TPHE significantly suppressed the carcinogenic effect of LA7 tumour cells. The tumour sections from TPHE-treated rats demonstrated significantly reduced expression of Ki67 and PCNA compared to the cancer control group. Using a bioassay-guided approach, the cytotoxic compound of TPHE was identified as a tricyclic sesquiterpene lactone, namely, $8 \beta$ - hydroxyl- $4 \beta, 15$ - dihydrozaluzanin C (HDZC). Signs of early and late apoptosis were observed in MCF7 cells treated with HDZC and were attributed to the mitochondrial intrinsic pathway based on the up-regulation of Bax and the down-regulation of Bcl-2. HDZC induced cell cycle arrest in MCF7 cells and increased the expression of p21 and p27 at the mRNA and protein levels. Conclusion: This results of this study substantiate the anticancer effect of TPHE and highlight the involvement of HDZC as one of the contributing compounds that act by initiating mitochondrial-mediated apoptosis.
\end{abstract}

Copyright (C) 2015 S. Karger AG, Basel

Hamed Karimian

and Mohamad Ibrahim Noordin

KARGER 125
Department of Pharmacy, Faculty of Medicine, University of Malaya,

50603 Kuala Lumpur (Malaysia)

Tel.+60379677520, E-Mail hamedkarimian61@gmail.com, E-Mail ibrahimn@um.edu.my 


\section{Introduction}

Breast cancer is the most prevalent cancer amongst females and presents an emerging major health problem, both socially and economically. In the United States, it is estimated that approximately 3 million women are living with a history of invasive breast cancer [1]. The metastasizing ability of breast cancer cells to various organs, mostly lymph nodes, lungs, the liver and bones, is accountable for the poor prognosis and high mortality rate in breast cancer patients [2]. Therefore, metastasis is still a high risk factor for medical practitioners involved in breast cancer treatment [3]. Furthermore, the development of resistance in breast cancer epithelial cells to currently used anticancer drugs is a growing challenge in the field of cancer therapy [4]. Although, theoretically, anticancer agents should target only tumour cells, there is a plethora of adverse side effects with the currently available treatments, including bleeding, immunosuppression, hair loss and diarrhoea [5].

Disruption of the native homeostatic mechanism or major perturbations in the cell lifecycle can affect the delicate maintenance of the entire population of a certain tissue. Consequently, the extreme increase of cell growth results in serious complications, such as invasion, metastasis and mechanical pressure [6]. These dramatic changes are mostly associated with a wider spread of the cancer, transformation from a benign to malignant tumour and/or resistant to conventional chemotherapies. A series of events can revolutionize the static state of the organ and initiate a drawback scenario in which unwanted diverse effects or an irreversible mutation may occur [7]. Nevertheless, it has been established that the evasion of apoptosis is one of the six critical changes in cell physiology that can lead to the development of malignant growth $[8,9]$. In contrast, apoptosis (programmed cell death) is an important physiological hallmark that is responsible for regulating the generation or degeneration of newly born cells. Continuous insults and prolonged exposure to risk factors can alter the cross-talk between the cell and the surrounding tissue as well as the speed of the release of regulatory proteins and genes, including those related to apoptosis, i.e., Bax, Bcl-2, and caspases, among others [10]. In fact, new strategies for tumour eradication are often built upon the induction of apoptosis and the suppression of the cell cycle cascade at critical phases [10].

Tanacetum polycephalum (L.) Schultz-Bip, a member of the Asteraceae family, is an aromatic perennial plant that grows in many regions of the Northern Hemisphere $[11,12]$. T. polycephalum has been reported to have antiallergic, anticancer, anti-irritant, antiseptic, analgesic and antihypertensive effects [13]. Previous studies have shown that the antiallergic and anti-inflammatory effects of this aromatic plant are due to the presence of sesquiterpene lactones and volatile oils $[14,15]$. In our previous report, we showed that the T. polycephalum hexane extract (TPHE) from leaves has selective cytotoxic effects against different cancer cell lines, including A549, CEMss, HepG2, HT29, MCF7, MDA-MB-231 and PC3. Further, we investigated the mitochondrial-mediated apoptotic effect of the extract on MCF7 breast cancer cells and detected a potent effect corresponding to an $\mathrm{IC}_{50}$ value of 6.42 $\pm 0.35 \mu \mathrm{g} / \mathrm{mL}$ [16]. The present study was designed to examine the chemopreventive activity of TPHE on the development and growth of LA7-induced breast cancer in rats. In addition, TPHE was subjected to a bioassay-guided approach to identify the cytotoxic compound $8 \beta$ hydroxyl- 4 $\beta$, 15- dihydrozaluzanin C (HDZC, Fig. 6) from T. polycephalum and to investigate its apoptosis-inducing effects.

\section{Materials and Methods}

Plant materials and the preparation of the extract

The leaves of T. polycephalum were collected from Shahrekord, Chaharmahal and Bakhtiari, Iran, in May 2013, and a voucher specimen was deposited at the Herbarium, Biological Institute, Shahrekord Azad University. Air-dried leaves were reduced to powder using a grinder. The powder of leaves (4 kg) was used 
Karimian et al.: Chemopreventive effects of Tanacetum polycephalum against breast cancer cells in vitro and in vivo

for hexane extraction at room temperature, and the filtrates were concentrated under reduced pressure using a Buchi R110 Rotavapor (Buchi Labortechnik AG, Flawil, Switzerland) at $40^{\circ} \mathrm{C}$.

\section{Cell culture maintenance and viability}

LA7 (rat mammary tumour cells), MCF10A (human breast epithelial cells) and MCF7 (human breast cancer cells) cell lines were purchased from American Type Cell Collection (ATCC, Manassas, VA, USA) and maintained in DMEM, MEBM (Sigma, St. Louis, MO, USA) or RPMI-1640 (Sigma) supplemented with $10 \%$ foetal bovine serum (FBS, Pasching, Austria) in a $37 \stackrel{\circ}{\mathrm{C}}$ incubator with $5 \% \mathrm{CO}_{2}$ saturation. Medium containing $0.1 \%$ DMSO (Sigma) was used as a vehicle control for the in vitro assays.

\section{Animals}

Pathogen-free female Sprague Dawley rats aged 6-10 weeks were obtained from the Animal Facility of the Faculty of Medicine, University of Malaya, Kuala Lumpur, Malaysia. They were housed at $25 \pm 3^{\circ} \mathrm{C}$ with a relative humidity of $55-60^{\circ} \mathrm{C}$ (a cycle of $12 \mathrm{~h}$-light and $12 \mathrm{~h}$-dark) and were provided with standard food pellets and tap water ad libitum. The animal studies were sanctioned and approved by the Institutional Animal Ethical Committee (FAR/26/07/2013HK).

\section{Experimental design and animal treatment}

A total of thirty female rats were randomly divided into five different groups $(n=6)$. The animals were classified as group A-E. Group A consisted of the non-treatment LA7-induced non-treated tumour control animals, group B consisted of animals treated with a low dose $(250 \mathrm{mg})$ of TPHE, group C consisted of animals treated with a high dose $(500 \mathrm{mg})$ of TPHE, group D consisted of animals treated with tamoxifen, and group E consisted of animals that were the normal control group. For treatment, TPHE and tamoxifen were dissolved in Tween-20 and fed orally to the rats once a day for 6 weeks using gastric tubes two weeks before LA7 cell injection. The body weight of each rat was recorded weekly. At the end of the experiment, all of the rats were sacrificed via $\mathrm{CO}_{2}$ asphyxiation. Mammary tissue samples were obtained, washed twice with ice-cold PBS and kept for histopathological analyses.

\section{Induction of mammary gland tumours}

After reaching 90\% of confluence, LA7 cells grown in DMEM medium were removed from the medium and the monolayer was washed with PBS. The cells were then detached from the culture flask by adding trypsin (EDTA). The cells were placed into a falcon tube and centrifuged at $1800 \mathrm{rpm}$ for $5 \mathrm{~min}$ at $4{ }^{\circ} \mathrm{C}$ and then washed with PBS. The cells were then counted using a haemocytometer. The cell suspensions were used within one h of harvesting. LA7 cell suspensions containing $5 \times 10^{6}$ cells in $300 \mu \mathrm{l}$ of PBS were injected subcutaneously into the left flank mammary fat pad of each rat using a tuberculin syringe and a 21-gauge needle.

\section{Tumour growth}

To monitor mammary tumour development, the diameters of the tumours were measured and recorded vertically and horizontally. Tumour volume (V) was calculated by the modified ellipsoidal formula: $\mathrm{V}=\left(a b^{2}\right) / 2$, where ' $a$ ' and ' $b$ ' are the longest and shortest diameter of the tumour, respectively.

\section{Histopathological examination}

The breast tumours were inserted in blocks, fixed with $10 \%$ buffered formalin and embedded in paraffin. The blocks were sectioned into approximately $5 \mu \mathrm{m}$ thick sections, which were then stained with Hematoxylin \& Eosin (H \& E). The stained sections were then evaluated and images were captured using light microscopy (Olympus BX51, Tokyo, Japan) by a histopathologist who was blinded to the treatment assignments.

\section{TUNEL assay}

The TUNEL assay was used to measure fragmented DNA in apoptotic cells by combining flourescein-12dUTP (a) at 3'-OH DNA ends using the terminal recombinant deoxynucleotidyl transferase enzyme (rTdT). The mammary tumour tissues were subjected to the DeadEnd Fluorometric TUNEL system according to the manufacturer's instructions (Promega Inc., Madison, WI, USA). Then, the sections were evaluated and 
Karimian et al.: Chemopreventive effects of Tanacetum polycephalum against breast cancer cells in vitro and in vivo

images were captured and analysed under a confocal microscope (Zeiss LSM 510, Zeiss, Thornwood, NY, USA) using standard fluorescein filters.

\section{Immunohistochemistry}

The paraffin sections were fixed with formaldehyde and were then subjected to graded alcohol dehydration and embedded in paraffin. The sections were incubated with primary antibodies against PCNA, Ki67, Bax, Bcl-2, Caspase 3, p21, p27 and p53 (Santa Cruz Biotechnology, Santa Cruz, CA, USA) and were incubated with a biotinylated secondary antibody. Colorimetric detection was performed using a DAB detection kit (Dako, Glostrup, Denmark). Images were captured using a light microscope (Olympus BX51).

\section{General experimental procedures}

Column Chromatography (CC) was run on silica gel $60(40-63 \mu \mathrm{m})$, while TLC was performed on aluminium and glass plates pre-coated with silica gel $60 \mathrm{~F}_{254}$ (Merck, Germany). UV spectra were recorded on a Shimadzu UV-160A spectrophotometer using $\mathrm{MeOH}$ as a solvent, and $1 \mathrm{H}$ NMR and ${ }^{13} \mathrm{C}$ NMR spectra were collected (JEOL JNM-FX500). The separation step was performed using HPLC with a PDA detector and an ODS, C-18 column (Phenomenex). MS was obtained using an Agilent 6530 and FT-IR: Perkin-Elmer RX 1 (Fourier transform infra-red) spectrometer was utilized to analyse the IR at frequencies of $4000-400 \mathrm{~cm}^{-1}$.

\section{Cell viability analysis}

Cell viability analysis was carried out using a MTT (3-(4,5-dimethylthiazol-2-yl)-2,5diphenyltetrazolium) assay as previously described [17]. Briefly, cells in the exponential growth phase were treated with HDZC at different concentrations $(0.39 \mu \mathrm{g} / \mathrm{mL}$ to $50 \mu \mathrm{g} / \mathrm{mL})$ in 96 -well plates and were incubated for 12, 24 and $48 \mathrm{~h}$. Cells treated with tamoxifen (Sigma) were used as the positive controls. After incubation, MTT dye ( $5 \mathrm{mg} / \mathrm{mL}, 50 \mu \mathrm{l}$, Sigma) was added to each well, and the resulting formazan crystals were dissolved using DMSO $(200 \mu \mathrm{l}$ ). Absorbance was measured at $570 \mathrm{~nm}$ using a microplate reader (Asys UVM340, Eugendorf, Austria), and the anti-proliferative potential of HDZC was expressed as the $\mathrm{IC}_{50}$ value.

\section{Bioassay-guided fractionation and isolation of the compounds}

Hexane crude extract ( $4.6 \mathrm{~g})$ was chromatographed on a silica gel 60 column $(40-63 \mu \mathrm{m}$ particle size) and eluted sequentially with Hexane $/ \mathrm{CH}_{2} \mathrm{Cl}_{2}$ mixtures $(70: 30 \rightarrow 0: 100)$. Eluates were collected, and those displaying similar $R_{f}$ values on TLC were pooled to yield ten fractions $\left(F_{1}-F_{10}\right)$. Fraction $F_{9}(0.53 \mathrm{~g})$ was further purified by micro column chromatography using $\mathrm{CH}_{2} \mathrm{Cl}_{2} / \mathrm{MeOH}(80: 20 \rightarrow 0: 100)$ and was separated into 6 and 4 sub fractions $\left(\mathrm{F}_{91}-\mathrm{F}_{96}\right)$ and $\left(\mathrm{F}_{951}-\mathrm{F}_{954}\right)$ (Fig. 7). The separation of fraction $\mathrm{F}_{953}(0.23$ g) by preparative HPLC with a ODS C-18 $4.6 \times 250 \mathrm{~mm}, 5.0 \mu \mathrm{m}, 70 \mathrm{~A}$ column and the mobile system of (50-100\% ACN- $\mathrm{H}_{2} \mathrm{O}$, detection at $210 \mathrm{~nm}, 7 \mathrm{~mL} / \mathrm{min}$ ) successively yielded a single chromatogram that was identified as $8 \beta$ - hydroxyl- $4 \beta, 15$ - dihydrozaluzanin C $1(1,5 \mathrm{mg}, 0.0025 \%)$. This is the first time that $8 \beta$ -

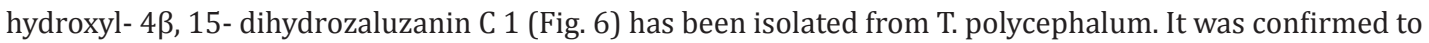
be tricyclic sesquiterpene lactone by comparing NMR, mass and other physical properties with previously reported data [18].

\section{Characterization data}

The white amorphous solids were characterized as follows: UV (MeOH), ${ }_{\text {max }} 271,338 \mathrm{~nm}$; IR ( $\left.\mathrm{CHCl}_{3}\right)$, $\max 3401,1704 \mathrm{~cm}^{-1}$; LCMS m/z $264.14[\mathrm{M}+\mathrm{H}]^{+}$- $\left(\right.$calcd for $\left.\mathrm{C}_{15} \mathrm{H}_{20} \mathrm{O}_{4}\right) ;{ }^{1} \mathrm{H}$ NMR $\left(\mathrm{CDCl}_{3}, 500 \mathrm{MHz}\right), \delta 6.24(d, J=$ $5.8 \mathrm{~Hz}, 1 \mathrm{H}, \mathrm{H}-3 \alpha), \delta 5.53(d, J=3.1 \mathrm{~Hz}, 1 \mathrm{H}, \mathrm{H}-3 \beta), \delta 3.26(t, J=2.46 \mathrm{~Hz}, 1 \mathrm{H}, \mathrm{H}-3 \mathrm{a}), \delta 3.99(m, 1 \mathrm{H}, \mathrm{H}-4), \delta 1.53$, $2.30(m, 2 \mathrm{H}, \mathrm{H}-5), \delta 4.99(m, 2 \mathrm{H}, \mathrm{H}-6 \alpha$ and $\mathrm{H}-6 \beta), \delta 2.69(m, 1 \mathrm{H}, \mathrm{H}-7 \mathrm{a}), \delta 1.97(m, 2 \mathrm{H}, \mathrm{H}-7), \delta 4.28(m, 1 \mathrm{H}$, $\mathrm{H}-8), \delta 1.56(d, J=3.2 \mathrm{~Hz}, 3 \mathrm{H}, \mathrm{H}-9), \delta 3.20(m, 1 \mathrm{H}-\mathrm{H}-10), \delta 2.43(\mathrm{~m}, 1 \mathrm{H}, \mathrm{H}-10 \mathrm{a}), \delta 4.30(\mathrm{~m}, 1 \mathrm{H}, \mathrm{H}-11) ;{ }^{13} \mathrm{C} \mathrm{NMR}$

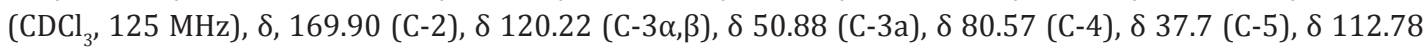
(C-6 $\alpha, \beta$ ), $\delta 52.42$ (C-7a), $\delta 36.13$ (C-7), $\delta 82.61$ (C-8), $\delta 24.47$ (C-9), $\delta 44.42$ (C-10), $\delta 47.41$ (C-10a), $\delta 83.08$ (C-11), $\delta 139.11$ (C-3), and $\delta 148.31$ (C-6) (Table 2).

\section{Cell cycle analysis}

Cycle progression in the cells treated with HDZC was examined using flow cytometric analysis [19]. In brief, MCF7 cells ( $5 \times 10^{4}$ cells $\left./ \mathrm{mL}\right)$, at the exponential phase of growth, were treated with HDZC at the 
Karimian et al.: Chemopreventive effects of Tanacetum polycephalum against breast cancer cells in vitro and in vivo

IC $_{50}$ concentration and incubated for 12,24 and $48 \mathrm{~h}$. After the incubation, the cells were harvested by trypsinization and washed twice with PBS (Sigma) prior to fixation with 70\% ethanol. The cells were then washed and stained with propidium iodide (PI, $1 \mathrm{mg} / \mathrm{mL}, 50 \mu \mathrm{L})$. RNase A $(1 \mathrm{mg} / \mathrm{mL}, 20 \mu \mathrm{L})$ was added to limit the binding of PI to the DNA molecules. The cycle distribution of 10,000 cells per sample was examined using the BD FACS Canto II flow cytometer (BD Biosciences, San Jose, CA, USA), and the results were analysed using the Cell Fit Cell analysis program.

\section{Annexin V-FITC analysis}

Flow cytometric analysis of early and late apoptosis was investigated using Annexin-V-FITC/PI staining [20]. Briefly, after treating the cells with HDZC at $\mathrm{IC}_{50}$ concentrations for 12,24 and $48 \mathrm{~h}$, MCF7 cells were harvested and washed twice with PBS. The cells were suspended in Annexin-V binding buffer (BD Biosciences) and were stained with Annexin V-FITC and PI (BD Biosciences) for 30 min in the dark. The fluorescent intensity was analysed via quadrant statistics for early and late apoptotic signs using a BD FACSCanto II flow cytometer.

\section{Caspase bioluminescent analysis}

The assay was carried out using Caspase-Glo 7 and Caspase-Glo 9 commercial kits (Promega, Madison, WI, USA) as previously described [21]. Briefly, MCF7 cells $\left(1 \times 10^{5}\right.$ cells $\left./ \mathrm{mL}\right)$ were seeded onto a white 96well microplate and were treated with $\mathrm{HDZC}$ at an $\mathrm{IC}_{50}$ concentration followed by incubation for $3,6,12$, 24 and $48 \mathrm{~h}$. The cells were then supplemented with caspase-Glo reagents according to the manufacturer's instructions. The bioluminescent activity of the caspases was measured using the Infinite-200 Pro luminescence microplate reader (Tecan, Männedorf, Switzerland).

\section{Real-time Q-PCR analysis}

The time-dependent mRNA expression of apoptotic related genes in treated breast cancer cells was examined using quantitative PCR analysis [22]. In brief, the RNeasy plus commercial kit (Qiagen, Valencia, CA, USA) was used to extract total RNA from MCF7 cells after treatment with the $\mathrm{IC}_{50}$ concentration of HDZC. cDNA synthesis from extracted RNA was performed using an iScript cDNA synthesis kit (Bio-Rad, Hercules, CA, USA) according to the manufacturer's protocol. Q-PCR analysis was performed with SsoFast EvaGreen Supermix (Bio-Rad) on a StepOne PLUS real-time PCR machine (Applied Biosystems, Foster City, CA, USA). The mRNA expression of genes was expressed after normalization with the $\beta$-actin housekeeping gene. The IDs for Solaris Gene Expression (Thermo Fisher Scientific, Waltham, MA, USA) Assays used in this study are Bax: AX-003308-00-0100; Bcl-2: AX-003307-00-0100; Caspase-7: AX-004407-00-0100; Caspase-9: AX003309-00-0100; p21: AX-003471-00-0100; p27: AX-003472-00-0100 and $\beta$-actin, AX-003451-00-0100.

\section{Western blot analysis}

A time-dependent western blot analysis was performed as previously described by Hajrezaie and colleagues with some modifications [23]. In brief, the total proteins were extracted from treated cells using Pierce cell lysis buffer (Rockford, IL, USA) according to the manufacturer's instructions. Extracted proteins $(40 \mu \mathrm{g} / \mathrm{mL})$ were separated by $10 \%$ SDS-PAGE and transferred to PVDF membrane (Bio-Rad). Casein (Pierce) was used to block the PVDF membrane prior to washing with TBST. The membrane was incubated overnight with specific primary antibodies, namely, Bax: 1:10,000 (Cat: sc-493); Bcl-2: 1:10,000 (Cat: sc492); Caspase 7: 1:10,000 (Cat: sc-33773); Caspase 9: 1:10,000 (Cat: sc-7885); p21: 1:10,000 (Cat: sc-397); p27: 1:10,000 (Cat: sc-528) and $\beta$-actin, 1:10,000 (Cat: sc-7210) (Santa Cruz Biotechnology, Inc., CA, USA). After incubation, appropriate peroxidase-coupled secondary antibodies were applied to the blot and the detection of bands was carried out using the Fusion FX7 system (Vilber Lourmat, Germany).

\section{Statistical analysis}

Data from the in vivo study were reported as the means \pm SEM of $\mathrm{n}$ animals per group. The in vitro results for at least three independent experiments were expressed as the mean value \pm SEM, and the differences were considered to be significant at the ${ }^{*} p<0.05$ level. Statistical analysis was carried out using GraphPad prism (version 4.0 Graphpad software Inc., San Diego, CA, USA). Analyses of variance were performed using the one-way ANOVA procedure followed by Tukey's post hoc test. 
Karimian et al.: Chemopreventive effects of Tanacetum polycephalum against breast cancer cells in vitro and in vivo

Table 1. Tumor size and body weight of rats. I. Normal control group (NC), II. Tumor control group (TC), III. Tumor treated with low dose of TPHE (TT + LD), IV. Tumor treated with high dose of TPHE (TT + HD), V. Tumor treated with tamoxifen (TT + TAM). Values are given as mean \pm SEM for six rats in each group. Oneway ANOVA followed by post hoc test. ${ }^{*} p<0.05$ compared with the control group

\begin{tabular}{ccccc}
\hline Group & $\begin{array}{c}\text { Treatment } \\
\text { groups }\end{array}$ & $\begin{array}{c}\text { Body weight } \\
(\mathrm{g})\end{array}$ & $\begin{array}{c}\text { Tumor volume } \\
\left(\mathrm{mm}^{3}\right)\end{array}$ & $\begin{array}{c}\text { Reduction of tumor } \\
\text { percentage }(\%)\end{array}$ \\
\hline I & NC & $300.57 \pm 10.63$ & 0 & 0 \\
II & TC & $285.16 \pm 8.57$ & $2137 \pm 324$ & 0 \\
III & TT + LD & $273.61 \pm 10.41$ & $1781 \pm 248$ & 16.65 \\
IV & TT + HD & $254.68 \pm 15.38$ & $* 457 \pm 132$ & $* 78.61$ \\
V & TT + TAM & $212.93 \pm 14.42$ & $* 396 \pm 96$ & $* 81.46$ \\
VI & & & & \\
\hline
\end{tabular}

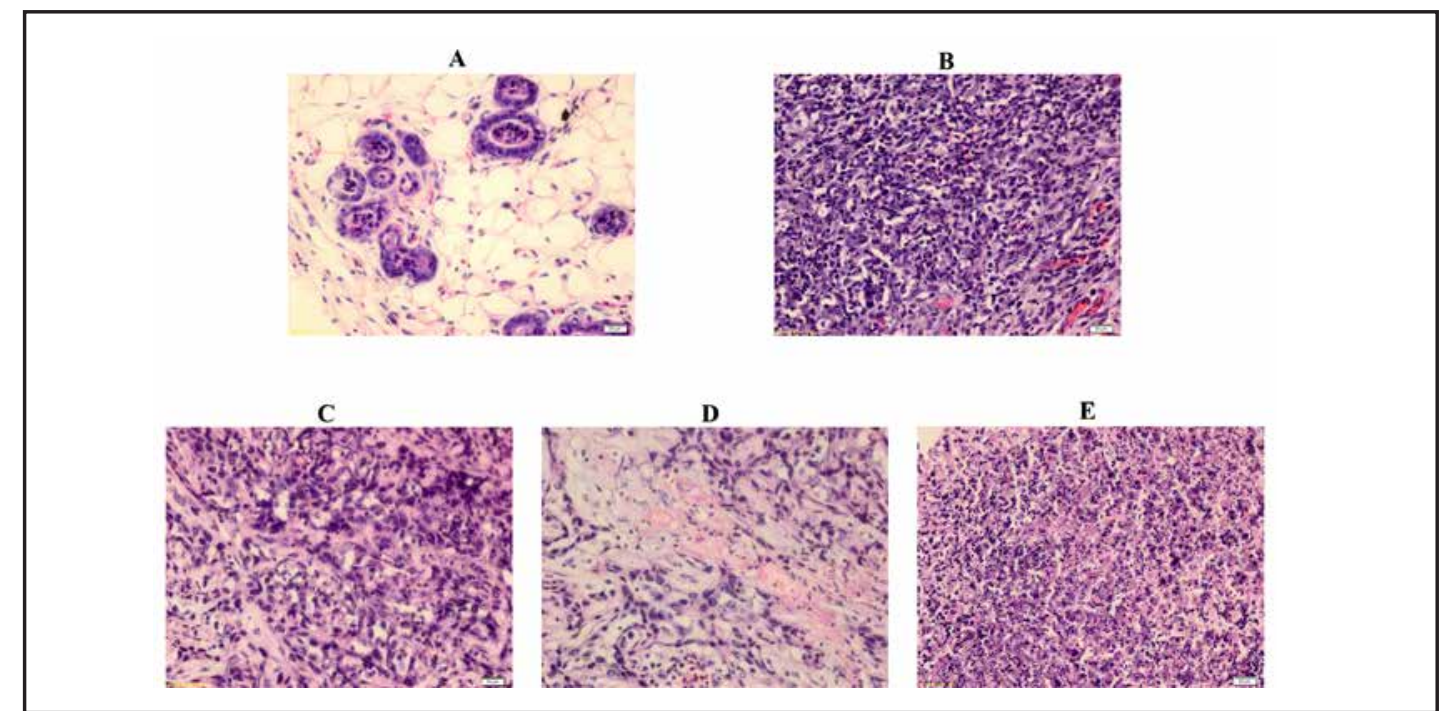

Fig. 1. Histological study of normal and treated breast cancer tissues. A) Normal breast tissue. B) Breast tumor induced by LA7. C) Breast tissue from low dose of TPHE treatment group. D) Breast tissue from high dose of TPHE treatment group E) Breast tissue from tamoxifen treated group. $\mathrm{H}$ and $\mathrm{E}$ staining of the tumor tissues shows morphological differences between normal breast tissues and cancerous breast tissue. The treatment of the tumor with TPHE shows reorganisation if the tumor part to the normal tissues. Magnification 40x.

\section{Results and Discussion}

Tumour development, body weight, tumour size and volume

Tumours appeared as early as 10 days after LA7 cell injections. The body weights, tumour volumes and tumour percentages (\%) of treated and control animals are represented in Table 1 . There was a significant body weight decrease in the cancer control group compared with the normal control animals, however, the low dose did not show any significant changes in weight compared to the controls.

Tumours in group A were enlarged up to $2,137 \pm 324 \mathrm{~mm}^{3}$; however, a significant decrease appeared in the high TPHE doses $\left(457 \pm 132 \mathrm{~mm}^{3}\right)$ and tamoxifen $\left(396 \pm 96 \mathrm{~mm}^{3}\right)$ treated groups compared with the tumour control group. The low dose of TPHE did not show a significant decrease in tumour size compared to the tumour control and tamoxifen group $(1,781 \pm 248 \mathrm{~mm})$, but the high dose of TPHE was shown to significantly reduce the tumour size comparable to tamoxifen treatment. Based on our finding of the size of the tumour and the body weight of the animal, we can conclude the efficacy of TPHE in reducing tumour size, which is associated with increases in body weight (Table 1). 
Karimian et al.: Chemopreventive effects of Tanacetum polycephalum against breast cancer cells in vitro and in vivo

\section{Histopathology}

Pleomorphism of the cells confirmed the induction of breast cancer tumours by LA7 cells (Fig. 1). Based on these results, we conclude that the development of the tumour was based on the invasive adenocarcinoma subtype with no tubular structure. In normal tissue, the duct was healthy and there was no sign of variation in size and shape; however, the untreated tumour showed a significant variation in the size and shape of the duct, followed by the disruption of the ductal structure (Fig. 1). Groups treated with high doses of TPHE had reduced mitotic events and smoothening of the tissue that led to the reorganization of the cells compared to the untreated group. However, normal rats treated with TPHE showed no changes in mammary gland morphology. Based on the morphology of the cells, the improved mammary gland structure was significantly more visible after treatment with high doses of TPHE and tamoxifen compared to the untreated cancer rats and there were no significant differences in the low dose treatment group.

\section{Apoptosis}

The TUNEL assay was used to determine whether inhibition of the tumour cells occurred through apoptosis. The tumour sections of the rats injected with breast cancer inducing LA7 showed significantly higher numbers of apoptotic cells after treatment with TPHE than the normal control and mammary tumour control rats. Indeed, the control groups showed very little or no obvious signs of apoptosis in the mammary glands (Fig. 2). Apoptotic cells were apparent in mammary tumour sections of all of the high dose TPHE- and tamoxifen-treated rats (Fig. 2).

\section{Immunohistochemistry}

The expression of cell nuclear antigen (PCNA) and Ki67 protein are closely associated to the proliferation of the tumour cells. The high levels of PCNA and Ki67 indicate an aggressive tumour prognosis. Immunohistochemical analysis of the cancer control group showed higher expressions of PCNA and Ki67 compared to the TPHE treatment groups. These findings demonstrate the promising chemopreventive
Table 2. NMR spectroscopic data ( $500 \mathrm{MHz}, \mathrm{CDCl}_{3}$ ) for compound $\mathbf{1}(\delta$ in ppm, $J$ in $\mathrm{Hz}$ )

\begin{tabular}{lcc}
\hline Position & ${ }^{1} \mathrm{H}-\mathrm{NMR}(\delta \mathrm{ppm})$ & ${ }^{13} \mathrm{C}-\mathrm{NMR}(\delta \mathrm{ppm}$ \\
\hline 1 & & \\
2 & & 169.90 \\
$3 \alpha$ & $6.24 \mathrm{~d}(5.8)$ & 120.22 \\
$3 \beta$ & $5.53 \mathrm{~d}(3.1)$ & \\
$3 \mathrm{a}$ & $3.26 \mathrm{t}(2.46)$ & 50.88 \\
4 & $3.99 \mathrm{~m}$ & 80.57 \\
5 & $1.53 \mathrm{~m}$ & 37.7 \\
& $2.30 \mathrm{~m}$ & \\
$6 \alpha$ & $4.99 \mathrm{~m}$ & 112.78 \\
$6 \beta$ & $4.99 \mathrm{~m}$ & \\
$7 \mathrm{a}$ & $2.69 \mathrm{~m}$ & 52.42 \\
7 & $1.97 \mathrm{~m}$ & 36.13 \\
8 & $4.28 \mathrm{~m}$ & 82.61 \\
9 & $1.56 \mathrm{~d}(3.2)$ & 24.47 \\
10 & $3.20 \mathrm{~m}$ & 44.42 \\
$10 \mathrm{a}$ & $2.43 \mathrm{~m}$ & 47.41 \\
11 & $4.30 \mathrm{~m}$ & 83.08 \\
3 & & 139.11 \\
6 & & 148.31 \\
\hline
\end{tabular}

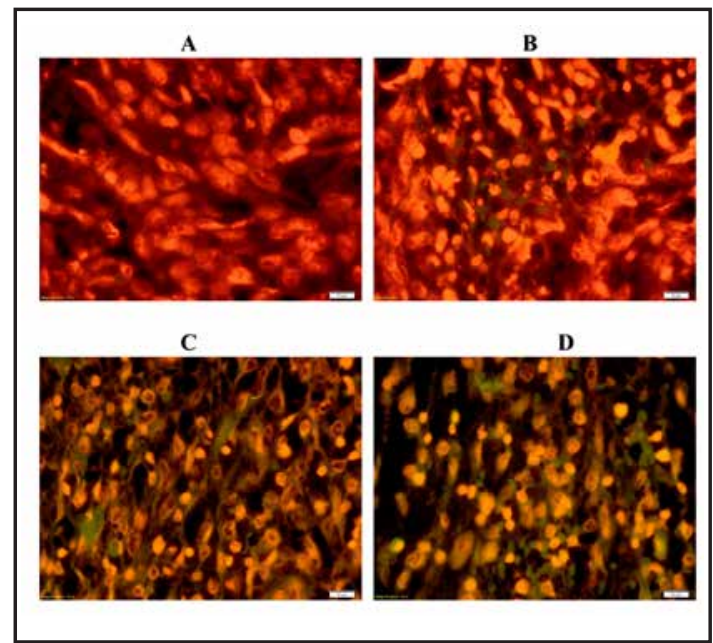

Fig. 2. Induced apoptosis of breast cancer cells as determined by the TUNEL assay. A) Control tumor tissue. B) Breast tissue from low dose of TPHE treatment group C) Breast tissue from high dose of TPHE treatment group. D) Breast tissue from tamoxifen treated group. Breast cancer tissue sections from the control and treatment group were subjected to the TUNEL assay. Tissue from the control group did not shows any significant changes in the color of the tissues While tissue from the high dose TPHE and tamoxifen treated groups showed a very high number of apoptotic cells. The low dose TPHE treated group did not show significant apoptotic activity. Magnification $40 \mathrm{x}$. 


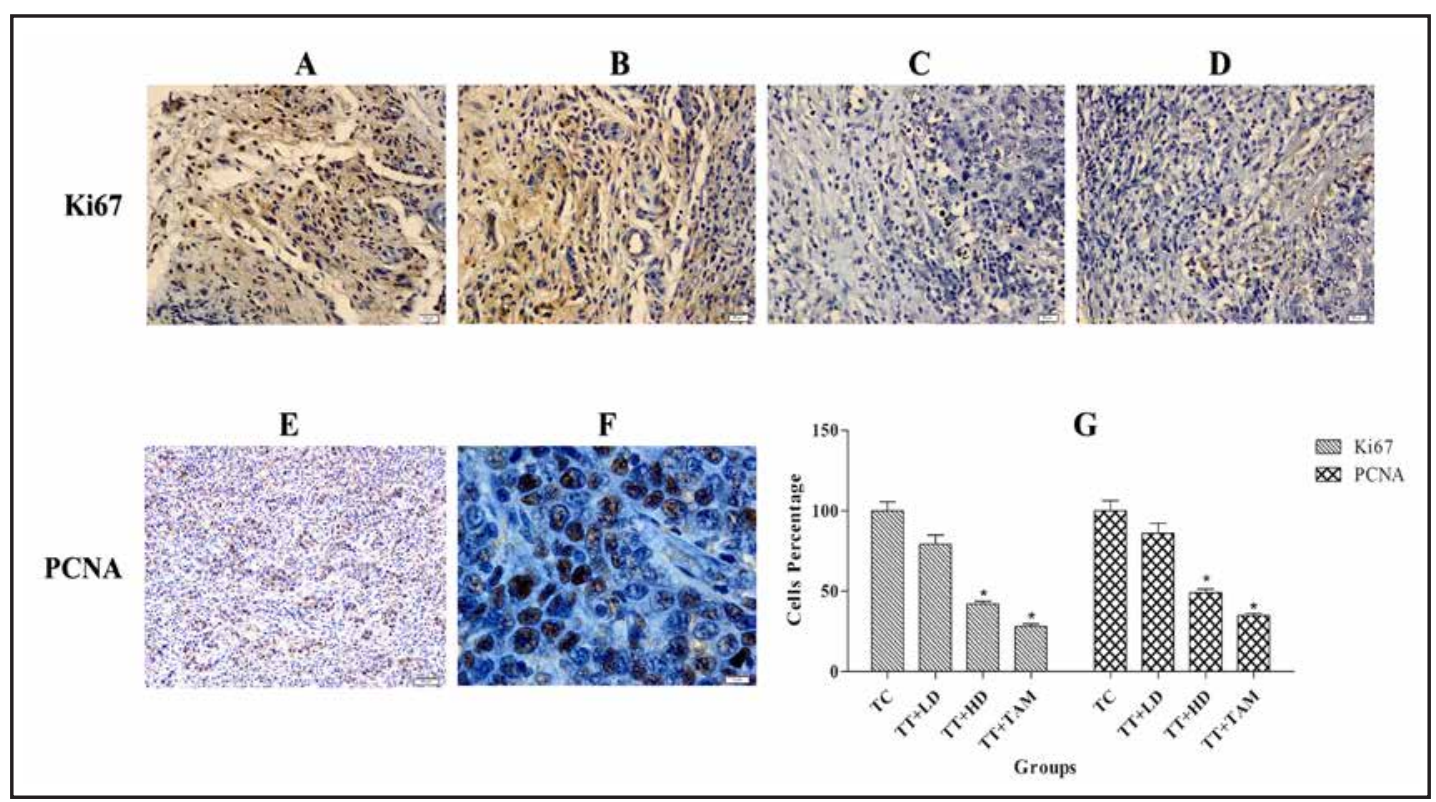

Fig. 3. Proliferation markers (Ki67 and PCNA) decreased after Treatment. A) Ki67 Tumor control B) Ki67 low dose TPHE treatment C) Ki67 high dose TPHE treatment D) Ki67 tamoxifen treatment E \& F) PCNA tumor control. Immunohistochemical staining with Ki-67 and PCNA shows the reduction of the Ki67 and PCNA markers after treatment with TPHE and tamoxifen in low and high dose treatment (G). The data represent the means \pm SEM of three independent experiments. ${ }^{*} p<0.05$ compared with the control group.

Fig. 4. Immunohistochemistry staining of Bax, Bcl-2, P53 and Caspase 3 proteins. A) Tumor control B) Low dose TPHE treatment C) High dose TPHE treatment D) tamoxifen treatment. The analysis of Bax and Bcl-2 shows an up-regulation of Bax, p53 and caspase 3 and down-regulation of $\mathrm{Bcl}-2$ which revealed the induction of apoptosis through mitochondrial pathway. Magnification 40x.

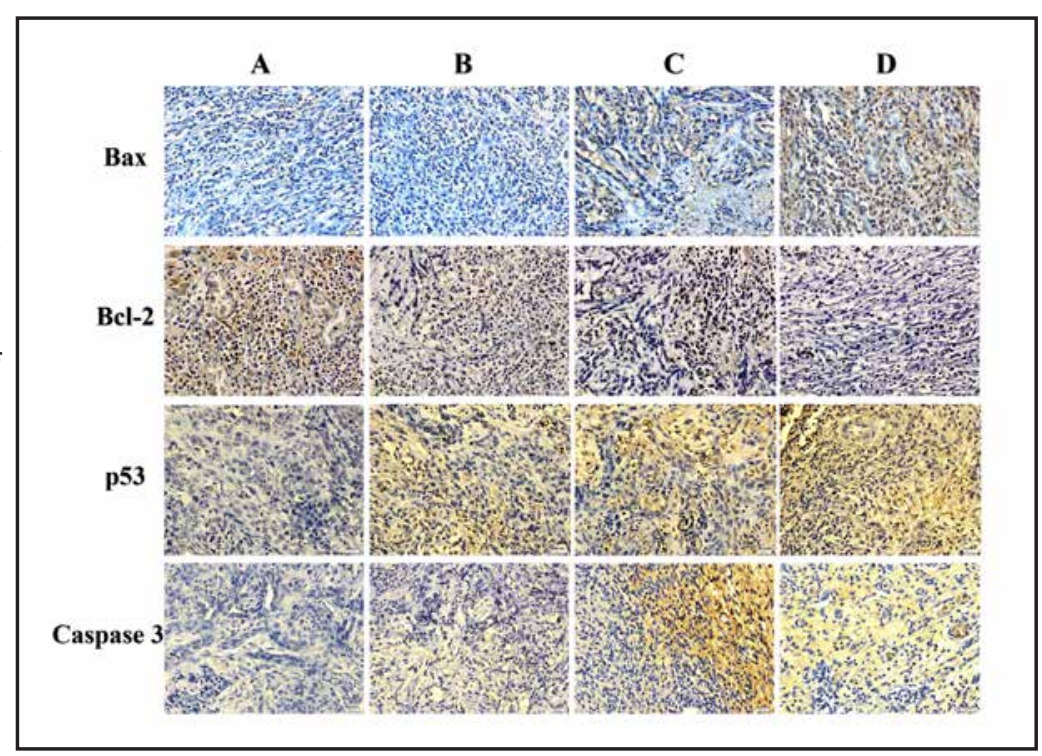

potential of TPHE, which was proven by the reduced protein expressions of tumour markers (Fig. 3).

Because the potency of TPHE in inducing apoptosis in breast cancer cells was previously reported to occur through the mitochondrial pathway [16], we investigated the expression of Bax, Bcl-2, caspase 3, p53, p21 and p27 proteins, as these proteins are implicated in the induction of apoptosis through intrinsic apoptosis pathways. The microscopic observations of the slides in Fig. 4 demonstrate the significant differences between the TPHE high dose and tamoxifen-treated groups in comparison to the tumour control group. The results represent the up-regulation of Bax, p53 and caspase 3 proteins and the down-regulation of the expression of Bcl-2 proteins. The low dose TPHE treated group was not significantly different compared to the positive control group (Fig 4). Immunohistochemical observations 
Karimian et al.: Chemopreventive effects of Tanacetum polycephalum against breast cancer cells in vitro and in vivo

Table 3. HDZC IC $_{50}$ concentration against MCF7 and MCF10A cells after treatment for 12,24 and $48 \mathrm{~h}$. The data represent the means \pm SEM of three independent experiments

\begin{tabular}{lcccccc}
\hline Cell line & & & \multicolumn{2}{c}{$\mathrm{IC} 50(\mu \mathrm{g} / \mathrm{mL})$} \\
& HDZC & Tamoxifen & HDZC & Tamoxifen & HDZC & Tamoxifen \\
& $12 \mathrm{~h}$ & $12 \mathrm{~h}$ & $24 \mathrm{~h}$ & $24 \mathrm{~h}$ & $48 \mathrm{~h}$ & $48 \mathrm{~h}$ \\
\hline MCF7 & $6.42 \pm 1.73$ & $3.30 \pm 0.58$ & $3.80 \pm 0.32$ & $2.60 \pm 0.63$ & $2.47 \pm 0.21$ & $1.5 \pm 0.15$ \\
MCF10A & $90.85 \pm 2.64$ & $70.09 \pm 1.79$ & $85.21 \pm 2.82$ & $54.59 \pm 1.08$ & $69.46 \pm 0.17$ & $32.46 \pm 2.54$ \\
\hline
\end{tabular}

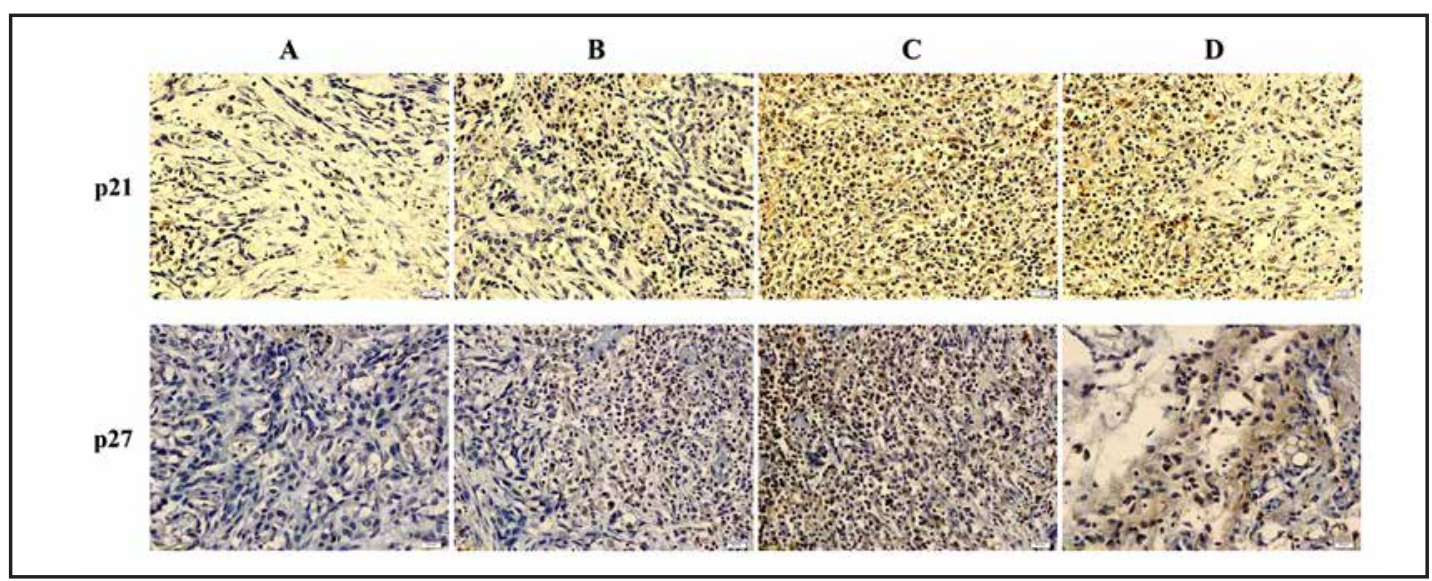

Fig. 5. Immunohistochemistry staining of p21 and p27 A) Tumor control B) Low dose treatment C) High dose treatment D) Tamoxifen treatment. Cell cycle arrest was confirmed by high expression of p21 and p27 proteins in treatment groups when compare to control group.

of $\mathrm{p} 21$ and p27 proteins in Fig. 5 revealed the up-regulation of these two proteins in the low and high TPHE dose groups, followed by up-regulation in the tamoxifen treated group.

Programmed cell death can be triggered through p53 expression associated with a transcriptional modulator, which can be closely mediated by the suppression or activation of other gene transcriptions [24]. The function of p53 is also closely related to the ratio of Bax/Bcl-2 proteins [25]. Tumours

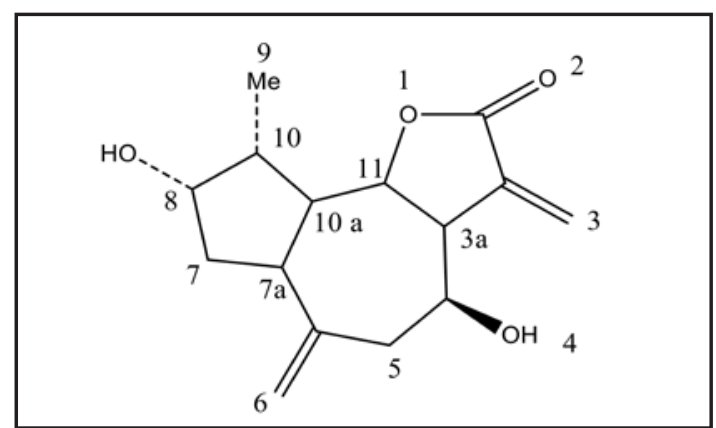

Fig. 6. Chemical structure of the compound HDZC.

with the loss of function of p53 are expected to have low levels of Bax and high levels of Bcl-2. In addition, the $\mathrm{G}_{1}$-S phase of cell cycle arrest can be closely mediated by the suppression or activation of the p53 gene, which has the ability to induce the cyclin-dependent kinase genes $\mathrm{p} 21 / \mathrm{p} 27$. Our results showed the up-regulation of the Bax protein and the down regulation of the Bcl-2 protein after treatment with a high dose of TPHE, while the tumour control group had low expressions of Bax and high expressions of Bcl-2 protein (Fig. 4), suggesting that apoptosis occurred through the mitochondrial pathway. The expression level of p53 was elevated in the high dose TPHE treatment group compared to the untreated control. The up-regulation of $\mathrm{p} 21 / \mathrm{p} 27$ in the high dose TPHE treatment group compared to the normal control group could be due to an arrest in the cell cycle progression (Fig. 5).

\section{Sesquiterpene lactones}

Sesquiterpene lactones, an extensive and diverse class of biologically active compounds, have been widely isolated from various plants belonging to the Asteraceae family [26]. Sesquiterpene lactones are a group of naturally occurring plant terpenoids representing crucial constituents of essential oils [27]. In recent years, numerous studies have 
Karimian et al.: Chemopreventive effects of Tanacetum polycephalum against breast cancer cells in vitro and in vivo

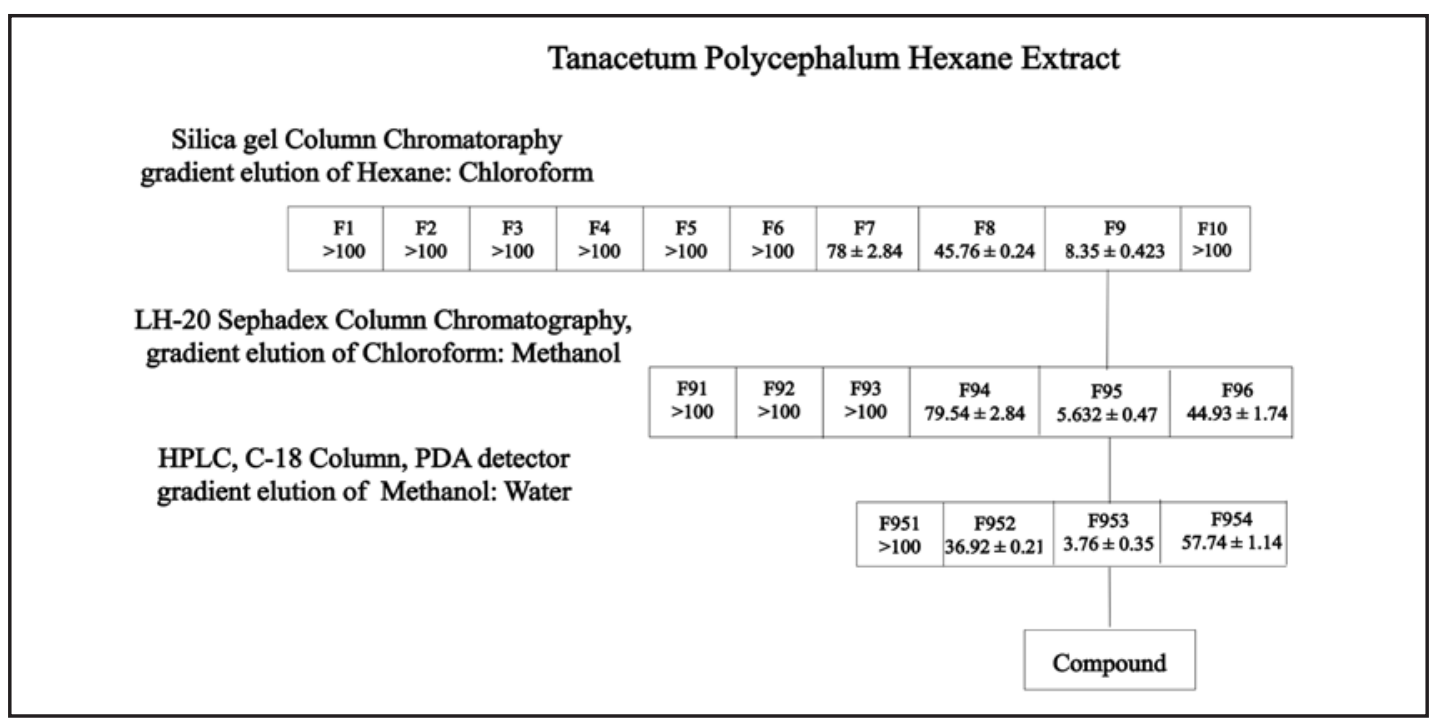

Fig. 7. Flow chart of bioassay-guided isolation of HDZC from the hexane extract of T. polycephalum leaves. Each fraction was subjected to MTT assay for the evaluation of its suppressive effect on MCF7 cells. IC ${ }_{50}$ values represent the means \pm SEM of three independent experiments.

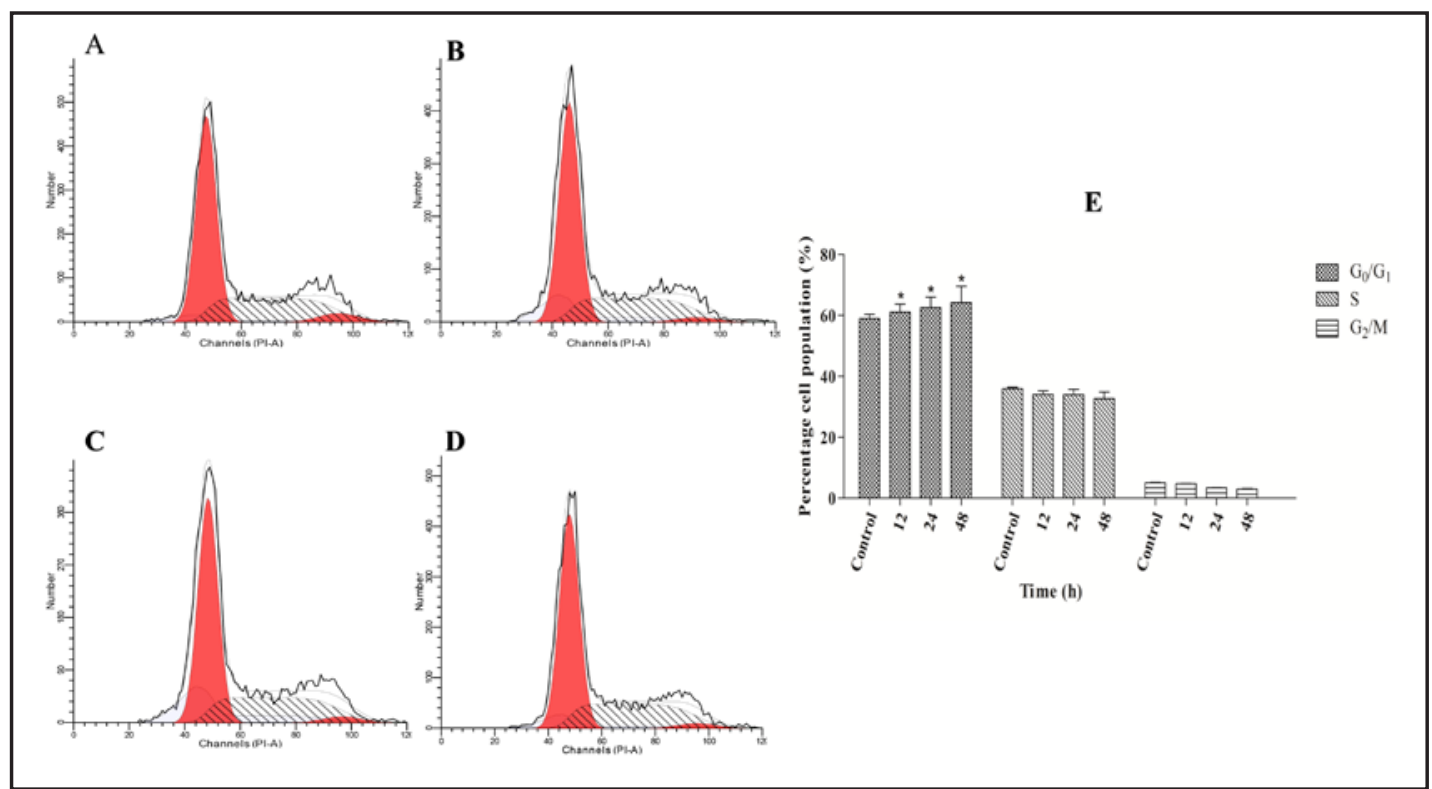

Fig. 8. Cell cycle analysis. Cell cycle analysis of MCF7 cells treated with (A) vehicle $0.1 \%$ DMSO (control) for $48 \mathrm{~h}$ and HDZC ( IC $_{50}$ concentration) for (B) 12, (C) 24 and (D) $48 \mathrm{~h}$. (E) The representative bar chart illustrated the significant $G_{1}$ cell cycle arrest after 12,24 and $48 \mathrm{~h}$. The data represent the means \pm SEM of three independent experiments. ${ }^{*} p<0.05$ compared with the control group.

demonstrated that different sesquiterpene lactones possess a notable anticancer potential $[27,28]$. For instance, costunolide isolated from Saussurea lappa roots [29], parthenolide isolated from Tanacetum parthenium [30-32] and helenalin isolated from Arnica species [33, $34]$ were reported to be anti-cancer sesquiterpene lactones. In this study, $8 \beta$ - hydroxyl- $4 \beta$, 15- dihydrozaluzanin C (Fig. 6) was isolated from T. polycephalum to assess its biological activity on human breast cancer cells.

HDZC selectively suppressed the growth of MCF7 cells

The antiproliferative effect of HDZC against a breast cancer cell line (MCF7) and a noncancer cell line (MCF10A) was screened using the MTT assay. As shown in Table 3, HDZC 


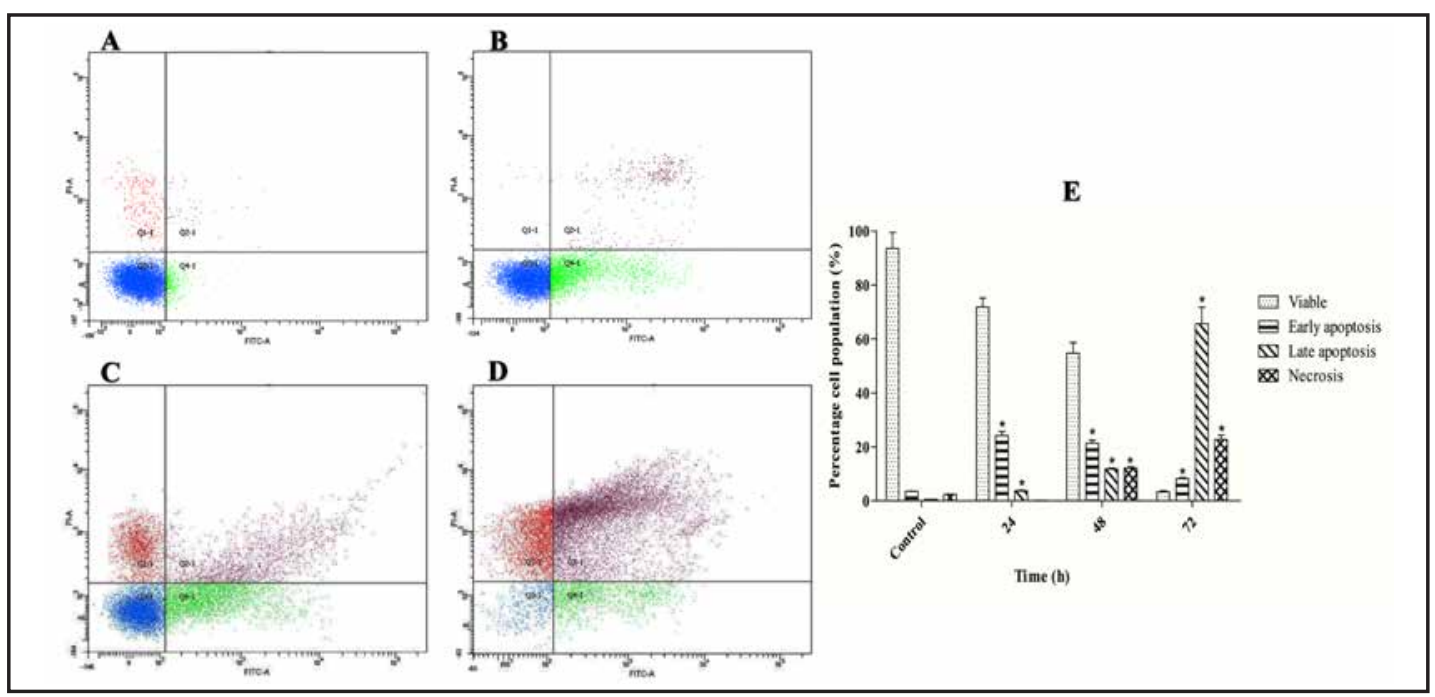

Fig. 9. Effect of HDZC on apoptosis rates in MCF7 cells. MCF7 cells was determined via quadrant statistics. Cell were treated with (A) vehicle $0.1 \%$ DMSO (control) for $48 \mathrm{~h}$ and HDZC (IC ${ }_{50}$ concentration) for (B) 12, (C) 24 and (D) $48 \mathrm{~h}$. (E) The representative bar chart illustrates the proportion of viable, early apoptotic, late apoptotic and necrotic MCF7 cells. The data represent the means \pm SEM of three independent experiments. ${ }^{*} p<0.05$ compared to the control group.

suppressed the growth of MCF7 cells at $\mathrm{IC}_{50}$ values of $6.42 \pm 1.73,3.80 \pm 0.32$ and $2.47 \pm 0.21$ $\mu \mathrm{g} / \mathrm{mL}$ after 12,24 and $48 \mathrm{~h}$, respectively. These results were comparable to the tamoxifen cytotoxic effect $(3.30 \pm 0.58,2.60 \pm 0.63,1.5 \pm 0.15 \mu \mathrm{g} / \mathrm{mL}$ after 12,24 and $48 \mathrm{~h}$, respectively). HDZC elicited a powerful effect against MCF7 cells compared to the hexane extract $\left(\mathrm{IC}_{50}\right.$ value of $6.42 \pm 0.35 \mu \mathrm{g} / \mathrm{mL}$ at $48 \mathrm{~h}$ of treatment) [16]. Meanwhile, proliferation of normal cells (MCF10A) was affected by HDZC solely at higher concentrations.

\section{HDZC induced G1 cell cycle arrest}

Flow cytometry analysis of MCF7 treated with HDZC indicated significant increases of the cell population in the $\mathrm{G}_{1}$ phase after 12, 24 and $48 \mathrm{~h}$ (Fig. 8). Arrest of the cell cycle progression is an effective approach for inhibiting the proliferation of cancer cells [35-37]. PI dye binds to DNA molecules at all cell cycle stages when applied to apoptotic cells, and thereafter, the emitted fluorescent intensity representing the DNA content of the cells is measured using flow cytometry analysis. Fig. 8 demonstrates the cell cycle phase distribution in MCF7 cells specific to each phase after treatment with HDZC at the $\mathrm{IC}_{50}$ concentration. Expression of the $\mathrm{G}_{1}$ phase was most evident in the MCF7 cells treated with HDZC (12 h: 61.13\%; 24 h: 62.64\%; 48 h: 64.25\%) relative to the control cells. The arrest of MCF7 cells at the $\mathrm{G}_{1}$ phase was associated with a consequent reduction in the percentage of cells at the $S$ and $G_{2} / M$ phases.

A previous study showed that costunolide sesquiterpene lactone induced $G_{1}$ cell cycle arrest in hormone dependent (LNCaP) and independent (PC-3 and DU-145) prostate cancer cells [38]. Similarly, parthenolide sesquiterpene, in combination with NS398, resulted in cell cycle arrest at the $G_{0} / G_{1}$ phase in Hep3B, HepG2 and PLC human hepatocellular carcinoma cells [39]. Jang and co-workers reported a dose-dependent elevation in the sub $\mathrm{G}_{1}$ populations of human renal carcinoma Caki cells treated with helenalin sesquiterpene [34]. Consistently, our findings showed that HDZC, like other sesquiterpene lactones, arrested the cell cycle of the breast cancer cell line at the $\mathrm{G}_{1}$ phase.

\section{HDZC induced apoptosis in MCF7 cells}

The aforementioned results of the selective cytotoxic effect of HDZC towards MCF7 cells encouraged us to examine the early events of apoptosis. It has been well established 


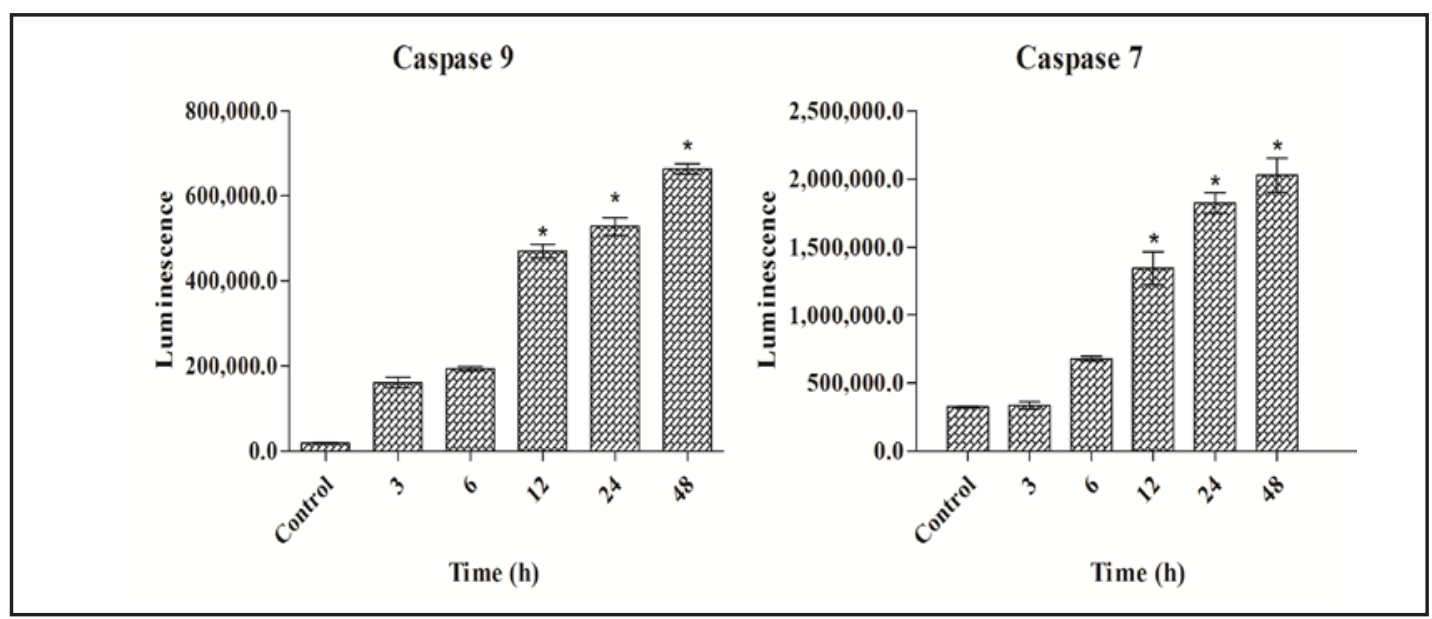

Fig. 10. Effect of HDZC on the activation of caspase 9 and caspase 7. The caspase 7 and 9 on MCF7 cells was determined using a bioluminescent analysis. MCF7 cells were treated with the vehicle $0.1 \%$ DMSO (control) for $48 \mathrm{~h}$ and HDZC ( IC $_{50}$ concentration) for 3, 6, 12, 24 and $48 \mathrm{~h}$. Caspase 9 and caspase 7 were significantly activated after 12,24 and $48 \mathrm{~h}$ treatment. The data represent the means \pm SEM of three independent experiments. ${ }^{*} p<0.05$ compared with the control group.

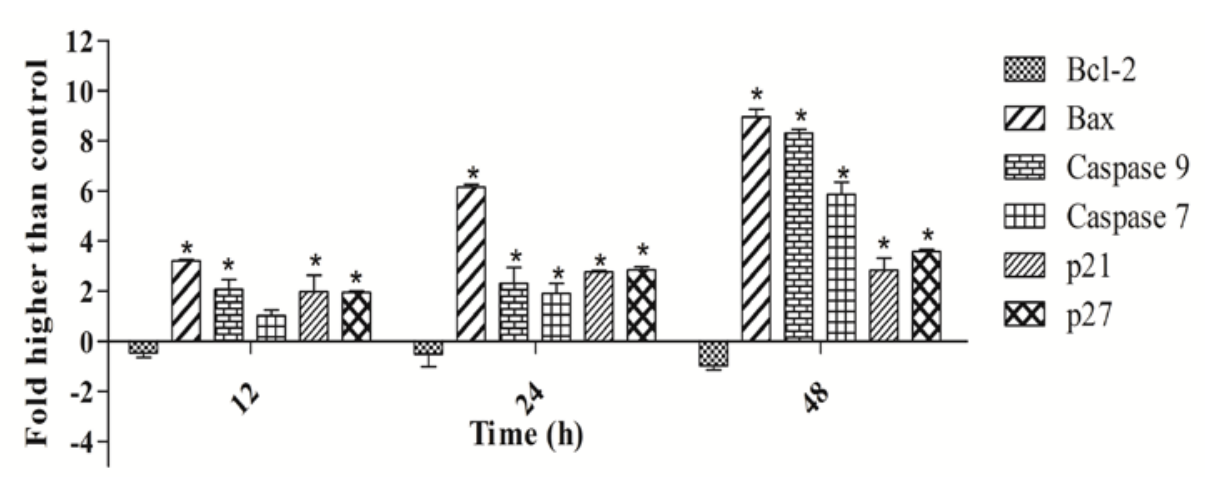

Fig. 11. Q-PCR analysis of apoptosis- and cell cycle-associated molecules, viz. Bcl-2, Bax, caspase 9, caspase 7, p21 and p27. MCF7 cells were exposed to HDZC at IC $_{50}$ concentration for 12,24 and $48 \mathrm{~h}$. The mRNA expression of genes was represented after normalization with $\beta$-actin housekeeping gene. The data represent the means \pm SEM of three independent experiments. ${ }^{*} p<0.05$ compared with the control group.

that during early apoptosis, plasma membrane asymmetry is lost because of the phosphatidylserine externalization [40]. Cancer is generally defined as a disease of abnormal cell growth; therefore, disruption or deformity of the cell plasma membrane means losing the cell architecture, leading to the discontinuity of their life cycle. Annexin V-FITC/PI followed by flow cytometry analysis is a methodology that is applied to examine the integrity of the cell external membrane [41]. We observed MCF7 cell membrane leakage with double staining with different intensities in accordance to the phase of apoptosis. As shown in Fig. 9 , in treated cells, early apoptotic cells (Annexin $\mathrm{V}^{+} / \mathrm{PI}^{-}$) and late apoptotic cells (Annexin $\mathrm{V}^{+} / \mathrm{PI}^{+}$) began to emerge as early as $12 \mathrm{~h}$ at proportions of $24.2 \%$ and $3.7 \%$, respectively, while control cells supplemented with a $0.1 \%$ DMSO vehicle elicited low or negative staining with both Annexin V-FITC and PI for visualized and well-survived viable cells. The number of the apoptotic cells increased significantly from 12 to $48 \mathrm{~h}$, and the different stages of the programmed cell death, from early apoptosis till necrosis, were clearly observed in a timedependent manner. However, our findings revealed a dominance of the late apoptotic phase (after $24 \mathrm{~h}$ ), suggesting that the HDZC mode of action may rely on a correlation between the cell cycle arrest and the loss of cell integrity. It is noteworthy that the elevation of necrotic cells (Annexin $\mathrm{V}^{-} / \mathrm{PI}^{+}$) reached $22.7 \%$ after $48 \mathrm{~h}$ of treatment. 
Karimian et al.: Chemopreventive effects of Tanacetum polycephalum against breast cancer cells in vitro and in vivo

Fig. 12. Western blot analysis of apoptosis- and cell cycle-associated molecules, viz. Bcl-2, Bax, caspase 9, caspase 7, p21 and p27. MCF7 cells were exposed to HDZC at IC $_{50}$ concentration for 12, 24 and 48 h. $\beta$-actin was used as a positive control. The data represent the means \pm SEM of three independent experiments.

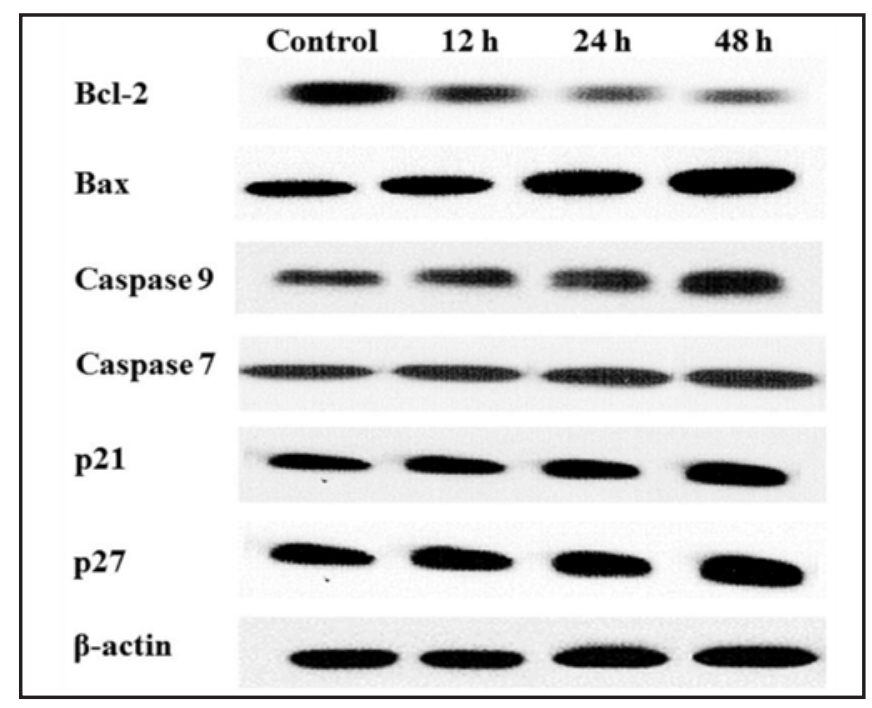

HDZC activated caspase 7 and caspase 9

Caspases, a family of cysteine proteases including at least 14 members, form a complex and energy-dependent cascade that executes apoptotic cells after a fatal insult [42]. The hierarchical organization of caspases generally consists of several initiator proteases (caspase 2, 8, 9, and 10), executioner or effector proteases (caspase 3,6, and 7) and inflammatory proteases (caspase 1,4, and 5) [43]. Caspase 9, in particular, is a key mediator of mitochondrial-mediated apoptosis, and the up-regulation of caspase 9 follows the upstream activation of caspase 7 prior to apoptosome formation and the fluctuation of the mitochondrial membrane potential [44]. To determine whether the induced apoptosis was caspase-mediated, we measured the activity of caspase 9 and caspase 7 in MCF7 cells using a bioluminescent analysis. Our studies indicated a significant time-dependent elevation of caspase 9 and caspase 7 (for example, the mRNA expression of caspase 9 and caspase 7 was 8.30 and 5.85-fold, respectively, after $48 \mathrm{~h}$ ) after treatment with HDZC in comparison to the control group (Fig. 10). However, the elevation of caspase 9 was higher than caspase 7, as observed in Fig. 11. Western blot analysis also confirmed the time-dependent enhancement of the expression of caspase 9 and caspase 7 (Fig. 12). Together, these results highlight the involvement of the intrinsic pathway of mitochondrial-derived apoptosis mediated by caspase 9 and caspase 7 dysregulation in MCF7 cells.

\section{The effect of HDZC on Bax/Bcl-2 expression}

Translocation of the pro-apoptotic Bax protein from the cytosol to the outer mitochondrial membrane and its oligomerization leads to changes in the mitochondrial membrane potential, both of which are associated with cytochrome $c$ leakage [45]. On the other hand, the suppression of cytochrome $c$ release is controlled by the anti-apoptotic Bcl2 protein $[46,47]$. Both the pro-apoptotic and anti-apoptotic proteins cause perturbations among mitochondrial-activated functions, such as those of caspase 9 [48]. Because HDZC elicited the ability to activate caspase 9 , it was of interest to determine the possible role of the two proteins, Bax and Bcl-2, in neutralizing this effect. Hence, we examined the mRNA and protein expression of these proteins using Q-PCR and western blot analysis. As shown in Fig. 11, Bax mRNA expression was elevated after $12 \mathrm{~h}$ and reached a 9-fold significant increase in the experimental groups compared to the control. Bcl-2 mRNA expression was found to decrease in a time-dependent fashion (Fig. 11). The results of the western blot analysis indicated that the up-regulation of Bax and the down regulation of Bcl-2 are additionally observed on the protein level (Fig. 12). These findings demonstrate that HDZC induced apoptosis by altering the regulation of apoptotic-related pro-proteins at both the mRNA and protein levels. 


\section{Cellular Physiology Cell Physiol Biochem 2015;36:988-1003 \begin{tabular}{l|l} 
and Biochemistry Published online: June 15, 2015 & $\begin{array}{l}\text { DO 2015 S. Karger AG, Basel } \\
\text { www.karger.com/cpb }\end{array}$ \\
\hline
\end{tabular} \\ Karimian et al.: Chemopreventive effects of Tanacetum polycephalum against breast cancer cells in vitro and in vivo}

The effect of HDZC on $p 21 / p 27$ expression

As accelerators of the cell cycle, cyclin-dependent kinases (CDKs) and their cyclin partners have a pivotal role in cell cycle progression and, accordingly, have been proposed to be key players in the suppression of accelerators $[49,50]$. Thus, the activation of cyclin dependent kinase inhibitors (CKIs) effectively adjusts the abnormal proliferation of cancer cells. The CKIs proteins p21 (CIP1) and p27 (KIP1) are members of the CIP/KIP family and are known to form heterotrimeric complexes that promote cell cycle arrest via the $\mathrm{G}_{1} / \mathrm{S}$ CDKs cascade [51]. Because HDZC possessed the ability to induce $\mathrm{G}_{1}$ cell cycle arrest in MCF7 cells, the next step was to elucidate the possible mechanism behind this outcome and to determine whether it includes the targeted accelerators/inhibitors. Hence, we examined the mRNA and protein expression level of p21 and p27 using Q-PCR and western blot analysis, respectively. The Q-PCR assay showed a significant up-regulation of the mRNA expression of $\mathrm{p} 21$ and p27, which reached 2.83 (p21) and 3.57 (p27)-fold higher levels compared to the controls after $48 \mathrm{~h}$ of HDZC treatment. As depicted in Fig. 12, western blot confirmed the perturbations in the mRNA expression of p21 and p27 at the protein level in a time-dependent manner. In sum, the up-regulation of p21 and p27 mediated by the introduction of HDZC treatment is part of the intrinsic pathway governed by mitochondrial genes and leads to the programmed death of cancer cells.

\section{Conclusions}

Our study demonstrates the in vivo chemopreventive activity of TPHE. Our results reveal the capability of TPHE to induce apoptosis in LA7-induced tumours in rats accompanied by caspase activation and the up-regulation of Bax and down-regulation of Bcl-2. Moreover, the exposure of tumour cells to TPHE caused cell cycle arrest, as was revealed by p21/p27 protein expression accompanied by p53 activation. The isolation of $8 \beta$ - hydroxyl- $4 \beta, 15-$ dihydrozaluzanin $\mathrm{C}$ sesquiterpene lactone from $T$. polycephalum is reported, to the best of our knowledge, for the first time. The bioassay guided approach revealed the potent cytotoxic effect of the sesquiterpene lactone. The accumulating body of data has shown the capacity of this class of compounds to act as anti-cancer agents. HDZC displayed a powerful and selective effect on cell survival, life cycles and integrity. In-depth molecular investigations were performed to illustrate the possible mechanisms of action. The elevated activity of caspase 9 associated with the up-regulation of Bax and the down-regulation of Bcl-2 proved that the induction of apoptosis in MCF7 is through the mitochondrial pathway. Additionally, HDZC caused cell cycle arrest at the $\mathrm{G}_{1}$ phase via alterations of the mRNA and protein expression of p21/p27. Collectively, our work suggests the promise of finding a renewable source of novel anti-cancer therapeutic agents from medicinal plants.

\section{Disclosure Statement}

No conflict of interest.

\section{Acknowledgements}

Financial support from the University of Malaya, the high impact research grant (UMMOHE UM.C/625/1/HIR/MOHE/SC/09) and the IPPP research grant (PG053/2012B) are greatly appreciated.

\section{References}

1 Siegel R, DeSantis C, Virgo K, Stein K, Mariotto A, Smith T, Cooper D, Gansler T, Lerro C, Fedewa S: Cancer treatment and survivorship statistics, 2012. CA Cancer J Clin 2012;62:220-241.

2 Lee SH, Jaganath IB, Wang SM, Sekaran SD: Antimetastatic effects of phyllanthus on human lung (A549) and breast (MCF-7) cancer cell lines. PloS One 2011;6:e20994. 
Karimian et al.: Chemopreventive effects of Tanacetum polycephalum against breast cancer cells in vitro and in vivo

3 Kennecke H, Yerushalmi R, Woods R, Cheang MCU, Voduc D, Speers CH, Nielsen TO, Gelmon K: Metastatic behavior of breast cancer subtypes. J Clin Oncol 2010;28:3271-3277.

4 Perez EA: Impact, mechanisms, and novel chemotherapy strategies for overcoming resistance to anthracyclines and taxanes in metastatic breast cancer. Breast Cancer Res Tr 2009;114:195-201.

$5 \quad$ Kranz D, Dobbelstein M: A killer promoting survival: P53 as a selective means to avoid side effects of chemotherapy. Cell Cycle 2012;11:2053-2054.

6 Altieri D: Survivin and IAP proteins in cell-death mechanisms. Biochem J 2010;430:199-205.

7 Reed JC: Drug insight: Cancer therapy strategies based on restoration of endogenous cell death mechanisms. Nat Rev Clin Oncol 2006;3:388-398.

8 Hanahan D, Weinberg RA: Hallmarks of cancer: The next generation. Cell 2011;144:646-674.

9 Gutschner T, Diederichs S: The hallmarks of cancer. RNA Biol 2012;9:703-719.

10 Fesik SW: Promoting apoptosis as a strategy for cancer drug discovery. Nat Rev Cancer 2005;5:876-885.

11 Chehregani A, Hajisadeghian S: New chromosome counts in some species of Asteraceae from Iran. Nord J Bot 2009;27:247-250.

12 Mahdavi M, Jouri M, Rezazadeh F: Identification of chemical compositions in the essential oil of Tanacetum polycephalum schultz-bip.(Iran). Int J Med Arom Plants 2013;3:395-400.

13 Mahdavi M, Jouri M, Mahmoudi J, Rezazadeh F, Mahzooni-Kachapi S: Investigating the altitude effect on the quantity and quality of the essential oil in Tanacetum polycephalum sch.-bip. Polycephalum in the baladeh region of nour, Iran. Chinese J Nat Med 2013;11:553-559.

14 Amiri H: Chemical composition, antibacterial and antioxidant activity of the essential oil of Tanacetum polycephalum schutz. Bip. Int J Bot 2007;3:321-324.

15 Morteza-Semnani K: Composition of the essential oil of Tanacetum polycephalum schultz bip. J Essent Oil Res 2006;18:129-130.

16 Karimian H, Mohan S, Moghadamtousi SZ, Fadaeinasab M, Razavi M, Arya A, Kamalidehghan B, Ali HM, Noordin MI: Tanacetum polycephalum (1.) schultz-bip. Induces mitochondrial-mediated apoptosis and inhibits migration and invasion in MCF7 cells. Molecules 2014;19:9478-9501.

17 Rouhollahi E, Moghadamtousi SZ, Paydar M, Fadaeinasab M, Zahedifard M, Hajrezaie M, Hamdi OAA, Looi CY, Abdulla MA, Awang K: Inhibitory effect of Curcuma purpurascens bi. Rhizome on HT-29 colon cancer cells through mitochondrial-dependent apoptosis pathway. BMC Complem Altern M 2015;15:15.

18 Cha M-R, Choi YH, Choi CW, Yoo DS, Kim YS, Choi SU, Ryu SY: New guaiane sesquiterpene lactones from Ixeris dentata. Planta Med 2011;77:380-382.

19 Hajrezaie M, Paydar M, Zorofchian Moghadamtousi S, Hassandarvish P, Gwaram NS, Zahedifard M, Rouhollahi E, Karimian H, Looi CY, Ali HM: A schiff base-derived copper (II) complex is a potent inducer of apoptosis in colon cancer cells by activating the intrinsic pathway. Sci World J 2014;2014:doi: $10.1155 / 2014 / 540463$.

20 Moghadamtousi SZ, Kadir HA, Paydar M, Rouhollahi E, Karimian H: Annona muricata leaves induced apoptosis in A549 cells through mitochondrial-mediated pathway and involvement of nf-kappab. BMC Complem Altern M 2014;14:299.

21 Moghadamtousi SZ, Kadir HA, Karimian H, Rouhollahi E, Paydar M, Fadaeinasab M: Annona muricata leaves induce $\mathrm{G}_{1}$ cell cycle arrest and apoptosis through mitochondria-mediated pathway in human HCT-116 and HT-29 colon cancer cells. J Ethnopharmacol 2014;156:217-289.

22 Karimian H, Moghadamtousi SZ, Fadaeinasab M, Golbabapour S, Razavi M, Hajrezaie M, Arya A, Abdulla MA, Mohan S, Ali HM: Ferulago angulata activates intrinsic pathway of apoptosis in MCF-7 cells associated with G1 cell cycle arrest via involvement of p21/p27. Drug Des Devel Ther 2014;8:1481.

23 Hajrezaie M, Hassandarvish P, Moghadamtousi SZ, Gwaram NS, Golbabapour S, NajiHussien A, Almagrami AA, Zahedifard M, Rouhollahi E, Karimian H: Chemopreventive evaluation of a schiff base derived copper (II) complex against azoxymethane-induced colorectal cancer in rats. PloS One 2014;9:e91246.

24 Ghashghaeinia M, Cluitmans JC, Toulany M, Saki M, Köberle M, Lang E, Dreischer P, Biedermann T, Duszenko M, Lang F: Age sensitivity of NFKB abundance and programmed cell death in erythrocytes induced by NFкB inhibitors. Cell Physiol Biochem 2013;32:801-813.

25 Zeng M, Xiao F, Zhong X, Jin F, Guan L, Wang A, Liu X, Zhong C: Reactive oxygen species play a central role in hexavalent chromium-induced apoptosis in Hep3B cells without the functional roles of p53 and Caspase-3. Cell Physiol Biochem 2013;32:279-290.

26 Toyang NJ, Wabo HK, Ateh EN, Davis H, Tane P, Sondengam LB, Bryant J, Verpoorte R: Cytotoxic sesquiterpene lactones from the leaves of Vernonia guineensis benth.(asteraceae). J Ethnopharmacol 2013;146:552-556. 
Karimian et al.: Chemopreventive effects of Tanacetum polycephalum against breast cancer cells in vitro and in vivo

27 Ghantous A, Gali-Muhtasib H, Vuorela H, Saliba NA, Darwiche N: What made sesquiterpene lactones reach cancer clinical trials? Drug Discov Today 2010;15:668-678.

28 Zhang S, Won Y-K, Ong C-N, Shen H-M: Anti-cancer potential of sesquiterpene lactones: Bioactivity and molecular mechanisms. Curr Med Chem 2005;5:239-249.

29 Robinson A, Kumar TV, Sreedhar E, Naidu V, Krishna SR, Babu KS, Srinivas P, Rao JM: A new sesquiterpene lactone from the roots of Saussurea lappa: Structure-anticancer activity study. Bioorg Med Chem Lett 2008;18:4015-4017.

30 Mathema VB, Koh Y-S, Thakuri BC, Sillanpää M: Parthenolide, a sesquiterpene lactone, expresses multiple anti-cancer and anti-inflammatory activities. Inflammation 2012;35:560-565.

31 Wu C, Chen F, Rushing JW, Wang X, Kim H-J, Huang G, Haley-Zitlin V, He G: Antiproliferative activities of parthenolide and golden feverfew extract against three human cancer cell lines. J Med Food 2006;9:55-61.

32 Guzman ML, Rossi RM, Karnischky L, Li X, Peterson DR, Howard DS, Jordan CT: The sesquiterpene lactone parthenolide induces apoptosis of human acute myelogenous leukemia stem and progenitor cells. Blood 2005;105:4163-4169.

33 Lim CB, Fu PY, Ky N, Zhu HS, Feng X, Li J, Srinivasan KG, Hamza MS, Zhao Y: Nf-кb p65 repression by the sesquiterpene lactone, helenalin, contributes to the induction of autophagy cell death. BMC Complem Altern M 2012;12:93.

34 Jang JH, Iqbal T, Min K-j, Kim S, Park J-W, Son E-I, Lee T-J, Kwon TK: Helenalin-induced apoptosis is dependent on production of reactive oxygen species and independent of induction of endoplasmic reticulum stress in renal cell carcinoma. Toxicol in Vitro 2013;27:588-596.

35 Schwartz GK, Shah MA: Targeting the cell cycle: A new approach to cancer therapy. J Clin Oncol 2005;23:9408-9421.

36 Alisi A, Demori I, Spagnuolo S, Pierantozzi E, Fugassa E, Leoni S: Thyroid status affects rat liver regeneration after partial hepatectomy by regulating cell cycle and apoptosis. Cell Physiol Biochem 2005;15:069-076.

37 Han ZB, Yang Z, Chi Y, Zhang L, Wang Y, Ji Y, Wang J, Zhao H, Han ZC: MicroRNA-124 suppresses breast cancer cell growth and motility by targeting CD151. Cell Physiol Biochem. 2013;31(6):823-32.

38 Hsu J-L, Pan S-L, Ho Y-F, Hwang T-L, Kung F-L, Guh J-H: Costunolide induces apoptosis through nuclear calcium $^{2+}$ overload and DNA damage response in human prostate cancer. J Urology 2011;185:1967-1974.

39 Ralstin MC, Gage EA, Yip-Schneider MT, Klein PJ, Wiebke EA, Schmidt CM: Parthenolide cooperates with ns398 to inhibit growth of human hepatocellular carcinoma cells through effects on apoptosis and g0-g1 cell cycle arrest. Mol Cancer Res 2006;4:387-399.

40 Leventis PA, Grinstein S: The distribution and function of phosphatidylserine in cellular membranes. Annu Rev Biophys 2010;39:407-427.

41 Zhang H, Guo M, Chen JH, Wang Z, Du XF, Liu PX, Li WH: Osteopontin knockdown inhibits $\alpha$ v, $\beta 3$ integrininduced cell migration and invasion and promotes apoptosis of breast cancer cells by inducing autophagy and inactivating the PI3K/Akt/mTOR pathway. Cell Physiol Biochem. 2014;33(4):991-1002.

42 Ocker M, Höpfner M: Apoptosis-modulating drugs for improved cancer therapy. Eur Surg Res 2012;48:111120.

43 Rai NK, Tripathi K, Sharma D, Shukla VK: Apoptosis: A basic physiologic process in wound healing. Int J Low Extr Wound 2005;4:138-144.

44 Mei Y, Yong J, Liu H, Shi Y, Meinkoth J, Dreyfuss G, Yang X: Trna binds to cytochrome c and inhibits caspase activation. Mol Cell 2010;37:668-678.

45 Youle RJ, Strasser A: The bcl-2 protein family: Opposing activities that mediate cell death. Nat Rev Mol Cell Bio 2008;9:47-59.

46 Suen D-F, Norris KL, Youle RJ: Mitochondrial dynamics and apoptosis. Gene Dev 2008;22:1577-1590.

47 Liu H, Lu S, Gu L, Gao Y, Wang T, Zhao J, Rao J, Chen J, Hao X, Tang SC. Modulation of BAG-1 expression alters the sensitivity of breast cancer cells to tamoxifen. Cell Physiol Biochem 2014;33(2):365-74.

48 Martinou J-C, Youle RJ: Mitochondria in apoptosis: Bcl-2 family members and mitochondrial dynamics. Dev Cell 2011;21:92-101.

49 Williams GH, Stoeber K: The cell cycle and cancer. J Pathol 2012;226:352-364.

50 Zhu Y, Wu J, Li S, Ma R, Cao H, Ji M, Jing C, Tang J: The function role of miR-181a in chemosensitivity to adriamycin by targeting Bcl-2 in low-invasive breast cancer cells. Cell Physiol Biochem 2013;32(5):12251237.

51 Weinl C, Marquardt S, Kuijt SJ, Nowack MK, Jakoby MJ, Hülskamp M, Schnittger A: Novel functions of plant cyclin-dependent kinase inhibitors, $\mathrm{ICK}_{1} / \mathrm{KRP}_{1}$, can act non-cell-autonomously and inhibit entry into mitosis. Plant Cell 2005;17:1704-1722. 